\title{
Difficulties in funding of VA-ECMO therapy for patients with severe accidental hypothermia
}

\author{
Sylweriusz Kosiński ${ }^{1,2}$, Tomasz Darocha ${ }^{3-5}$, Anna Jarosz ${ }^{6}$, Aleksandra Czerw ${ }^{7}$, Paweł Podsiadło ${ }^{5,8}$, \\ Tomasz Sanak ${ }^{9}$, Robert Gałązkowski ${ }^{5}$ 10, Jacek Piątek ${ }^{11}$, Janusz Konstanty-Kalandyk ${ }^{11}$, \\ Mirosław Ziętkiewicz ${ }^{6}$, Krzysztof Kusza ${ }^{12}$, Łukasz J. Krzych" ${ }^{4}$, Rafał Drwiła ${ }^{6}$ \\ ${ }^{1}$ Department of Anaesthesiology and Intensive Care, O. Sokołowski Specialist Hospital of Lung Diseases, \\ Zakopane, Poland \\ ${ }^{2}$ Tatra Volunteer Rescue Service, Zakopane, Poland \\ ${ }^{3}$ Department of Anaesthesiology and Intensive Care with Cardiac Monitoring Independent Public Central \\ Clinical Hospital No 7 of the Silesian Medical University in Katowice, Leszek Giec Upper-Silesian Medical \\ Centre, Katowice, Poland \\ ${ }^{4}$ Chair and Department of Anaesthesiology and Intensive Care, Medical University of Silesia in Katowice, Poland \\ ${ }^{5}$ Polish Air Rescue, Warsaw, Poland \\ ${ }^{6}$ Department of Anesthesiology and Intensive Care, Medical College of Jagiellonian University, \\ John Paul II Hospital, Krakow, Poland \\ ${ }^{7}$ Department of Public Health, Medical University of Warsaw, Poland \\ ${ }^{8}$ Polish Society for Mountain Medicine and Rescue, Szczyrk, Poland \\ ${ }^{9}$ Department of Disaster Medicine and Emergency Care, Chair of Anaesthesiology and Intensive Care, \\ Collegium Medicum Jagiellonian University, Krakow, Poland \\ ${ }^{10}$ Department of Emergency Medical Service, Medical University of Warsaw, Poland \\ ${ }^{11}$ Department of Cardiac Surgery, Vascular Surgery and Transplantology, Collegium Medicum, \\ Jagiellonian University, John Paul II Specialist Hospital in Krakow, Poland \\ ${ }^{12}$ Chair and Department of Anaesthesiology and Intensive Care, Poznan University of Medical Sciences, \\ Poznan, Poland
}

\begin{abstract}
Background: Severe accidental hypothermia is defined as a core temperature below 28 Celsius degrees. Within the last years, the issue of accidental hypothermia and accompanying cardiac arrest has been broadly discussed and European Resuscitation Council (ERC) Guidelines underline the importance of Extracorporeal Rewarming (ECR) in treatment of severely hypothermic victims. The study aimed to evaluate the actual costs of ECR with VA-ECMO and of further management in the Intensive Care Unit of patients admitted to the Severe Accidental Hypothermia Centre in Cracow, Poland. Methods: We carried out the economic analysis of 31 hypothermic adults in stage III-IV (Swiss Staging) treated with VA ECMO. Twenty-nine individuals were further managed in the Intensive Care Unit. The actual treatment costs were evaluated based on current medication, equipment, and dressing pricing. The costs incurred by the John Paul II Hospital were then collated with the National Health Service (NHS) funding, assessed based on current financial contract. Results: In most of the cases, the actual treatment cost was greater than the funding received by around 10000 PLN per patient. The positive financial balance was achieved in only 4 (14\%) individuals; other 25 cases (86\%) showed a financial loss. Conclusion: Performed analysis clearly shows that hospitals undertaking ECR may experience financial loss due to implementation of effective treatment recommended by international guidelines. Thanks to new NHS funding policy since January 2017 such loss can be avoided, what shall encourage hospitals to perform this expensive, yet effective method of treatment.
\end{abstract}


Hypothermia is defined as a core body temperature (Tc) below $35^{\circ} \mathrm{C}$ [1]. According to data from the Central Statistical Office, between 2009 and 2012, exposure to excessive natural cold was the initial cause of death of 1,835 people, 489 (27\%) of whom died in hospitals [2]. A questionnaire study carried out in 50 emergency departments that provide care for a population of over 4 million individuals revealed that the incidence of accidental hypothermia was 6 cases per 100,000 annually [3].

In several recent years, the issue of therapy for patients with severe stages of hypothermia, including cardiac arrest (stages III and IV according to the Swiss Staging System), has increasingly been disputed in the international literature. In the European Resuscitation Council guidelines, a Tc below $28^{\circ} \mathrm{C}$ accompanied by haemodynamic instability or cardiac arrest during hypothermia was considered an indication for extracorporeal rewarming (ECR) [4].

The success of medical management depends on the proper identification of patients, the administration of appropriate treatments, the coordination of actions at various levels of care and the availability of effective targeted therapies [5]. Based on the opinions of experts and the guidelines of the European Resuscitation Council, pre-hospital and hospital protocols for the management of patients with hypothermia were created $[1,4,6]$. The protocols enabled the comprehensive and organised use of advanced treatment methods for victims of severe hypothermia, including the initiation of ECR by a mobile team equipped with a portable extracorporeal membrane oxygenation (ECMO) system.

In an effort to meet the challenge of treating severely hypothermic patients, the Severe Accidental Hypothermia Centre (SAHC) was created within the Department of Anaesthesiology and Intensive Care at John Paul II Hospital in Cracow. The Centre treats patients in the same setting according to the same algorithm and by the same team, which provides a unique opportunity to estimate the costs of therapy (which have never been assessed before, according to some authors) and to analyse its cost effectiveness. The data obtained may be relevant for other centres interested in the implementation of ECR for hypothermic patients.

\section{METHODS}

The study's goal was to perform a financial analysis of venous-arterial extracorporeal membrane oxygenation (VA-ECMO) and to determine the general costs of therapy for patients with severe accidental hypothermia receiving intensive care at the Department of Anaesthesiology and Intensive Care in Cracow. The medical records of patients admitted to the Severe Accidental Hypothermia Centre between November 2013 and September 2016 were analysed. The study included 31 adult patients undergoing extracorporeal rewarming whose Tcs ranged from $15.2^{\circ} \mathrm{C}$ to $29^{\circ} \mathrm{C}$. The analysis involved the costs of the implementation of VA-ECMO and of patients'stays, including laboratory and microbiological tests, imaging examinations and transfusions of blood and blood-derived products. The costs were assessed based on the actual pricing of drugs, equipment and dressing materials purchased by the hospital. The hospital income resulted from funding from the National Health Fund (NFZ), which provided compensation for services classified as medical procedures.

\section{RESULTS}

The study group included 17 patients rewarmed during cardiac arrest and 14 patients with cardiogenic shock. The time between cardiac arrest and the initiation of extracorporeal therapy ranged from 107 to 345 minutes. In 2 patients, management was provided by the mobile ECR team.

In the cases of 29 (94\%) of the patients, the VA-ECMO system was implanted in the operating suite in the Department of Cardiology and the treatment continued in the Intensive Care Unit (ICU). Two patients died before admission to the ICU - one in the operating suite and one in the Emergency Department at the district hospital. The mean length of stay in the intensive care unit in the Department of Anaesthesiology and Intensive Care was 9 days.

In the group with sudden cardiac arrest (SCA), benefits from the treatment, such as stabilisation of the central temperature and the circulatory and respiratory systems, as well as recovery of consciousness and restitution of the baseline neurological condition, were observed in 8 out of 17 patients (46\%). Nine out of 17 patients died (53\%). In the group with cardiogenic shock, beneficial effects from the therapy were noted in 8 out of 14 patients $(57 \%) ; 6$ patients in that group (43\%) died.

The cumulative analysis of costs is presented in Table 1. The incurred costs in the entire study group were -189 314.99 PLN. The cost of extracorporeal rewarming for each patient exceeded the NHF refund by approximately 10,000.00 PLN. A positive financial balance was achieved in only 4 out of 29 patients who qualified for this therapy (14\%). Financial losses were noted for the remaining 25 patients (86\%).

\section{DISCUSSION}

The collation of costs with incomes revealed financial losses incurred by the service provider for the majority of patients due to the implementation of effective therapy recommended by the international guidelines and the assembly of experts.

Funding for the protocol of management elaborated and implemented in the Severe Accidental Hypothermia Centre is based on cooperation with the Department of Anaesthesiology and Intensive Care and the Department 
Tabela 1. Cumulative analysis of costs

\begin{tabular}{|c|c|c|c|c|c|c|c|c|c|}
\hline & \multicolumn{3}{|c|}{$\begin{array}{l}\text { Cardiac surgery } \\
\text { (PLN) }\end{array}$} & \multicolumn{3}{|c|}{$\begin{array}{l}\text { Intensive therapy } \\
\text { (PLN) }\end{array}$} & \multirow{2}{*}{$\begin{array}{l}\text { Total cost } \\
\text { of stay of } \\
30 \text { patients } \\
\text { including } \\
\text { drugs and } \\
\text { medical } \\
\text { procedures } \\
\text { (PLN) }\end{array}$} & \multirow[t]{2}{*}{$\begin{array}{l}\text { Total NHF } \\
\text { refund } \\
(\mathrm{PLN})\end{array}$} & \multirow[t]{2}{*}{$\begin{array}{l}\text { Final } \\
(\mathrm{PLN})\end{array}$} \\
\hline & $\begin{array}{l}\text { NHF } \\
\text { refund }\end{array}$ & $\begin{array}{l}\text { Costs of } \\
\text { ECMO } \\
\text { implantation } \\
\text { and removal }\end{array}$ & Balance & NHF refund & Costs & Balance & & & \\
\hline Sum total & $648,232.00$ & $541,263.31$ & $106,968.69$ & $674,331.32$ & $970,615.00$ & $-296,283.68$ & $1,511,878.31$ & $1,322,563.32$ & $-189,314.99$ \\
\hline $\begin{array}{l}\text { Average } \\
\text { per patient }\end{array}$ & $21,607.73$ & $18,042.11$ & $3,565.62$ & $22,477.71$ & $32,353.83$ & $-9,876.12$ & $50,395.94$ & $44,085.44$ & $-6,310.50$ \\
\hline
\end{tabular}

of Cardiac Surgery. The main accounting procedure from the catalogue of services (group code E02 - other cardiosurgical procedures) was listed by the Department of Cardiac Surgery, while the Department of Anaesthesiology and Intensive Care accounted for the treatment of patients based on the TISSS-28. According to the biding regulations, procedure 5.51.01.0005002 could have been performedonly by cardiac surgery departments, and its valuation was 404 points. In searching for alternative financing sources that would be adequate for the incurred costs, an attempt was made to consider ECMO therapy an obvious example of treatment for acute cardiopulmonary failure based on the recommendations of the National Supervisory Board and the National Consultant in Anaesthesiology and Intensive Therapy. In such cases, the major criterion for qualification is $\mathrm{PaO}_{2} / \mathrm{FiO}_{2}<70 \mathrm{~mm} \mathrm{Hg}$ at PEEP $\geq 10 \mathrm{~cm} \mathrm{H}_{2} \mathrm{O}$ that does not increase for at least 2 hours despite optimal, conventional ventilation therapy [7]. The time condition cannot be fulfilled in severe hypothermia since extracorporeal rewarming has to be initiated as quickly as possible, and any modifications of the parameters can cause cardiac arrest. Likewise, the interpretation of $\mathrm{PaO}_{2} /$ $/ \mathrm{FiO}_{2}$ in hypothermia is hindered due to cell metabolisms being critically reduced. Out of all of the patients treated, only one (who had concomitant aspiration pneumonia) fulfilled the required criteria.

A positive financial balance following treatment at the Department of Anaesthesiology and Intensive Care, which averaged 5,467.93 PLN, was achieved only for a small percentage of patients. Moreover, it should be stressed that in one case of a patient treated with ECMO by the mobile team in one of the district hospitals ( $\mathrm{TC} 15.2^{\circ} \mathrm{C}$, cardiac arrest), the expenses were not refunded, resulting in the additional loss of $24,680 \mathrm{PLN}$.

Several years of efforts in medical circles to ensure proper funding for extracorporeal rewarming in hypothermia resulted in the Directive of the Chairman of the National Health Fund No.129/2016/DSOZ on December 30, 2016. According to the Directive, the "ECMO - heart and lung support" procedure, which has a point value of 750, can be refunded in severe hypothermia cases. Accordingly, the centres that gave gone to great

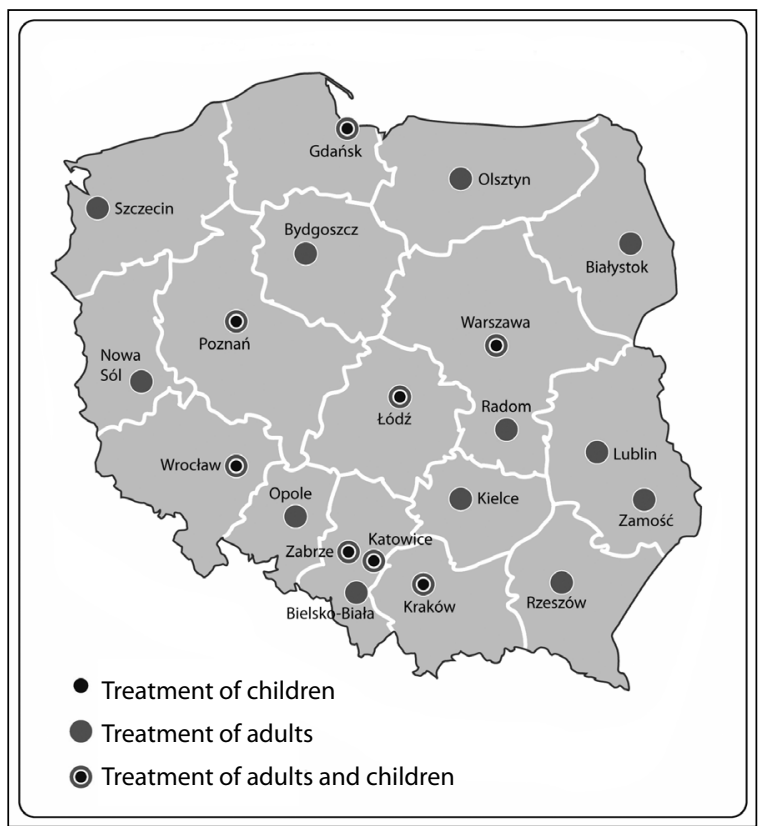

Figure 1. Distribution of centres dedicated to ECMO therapy in severely hypothermic victims

lengths to perform extracorporeal therapy in hypothermia ultimately have grounds for refunding the costs of treatment under novel, better conditions. Figure 1 presents the distribution of centres dedicated to ECMO therapy in severely hypothermic victims. The complete list of these centres is available at www.hipotermia.edu.pl.

Thanks to numerous educational activities undertaken by the Severe Accidental Hypothermia Centre, the guidelines of National Consultants [8] and advances in knowledge about hypothermia in Polish medical circles, the personnel of first-choice centres for the treatment of severely hypothermic patients will be able to register an increasingly high number of emergency notifications in the near future. Over a period of three years, the coordinators of the Severe Accidental Hypothermia Centre for Extracorporeal Therapy consulted 2005 hypothermic patients.

The use of ECMO in severe hypothermia is a recognised life-saving procedure. This has been confirmed by studies 
from other countries as well as from our Centre [9-12]. However, an adequate model of funding and suitable administrative solutions are relevant factors affecting therapeutic decisions. We hope that the economic aspects of our Centre's work and the options for extracorporeal rewarming funding presented above will dispel doubts and encourage other centres to implement this treatment method.

\section{CONCLUSIONS}

1. The use of venous-arterial ECMO in patients with severe hypothermia can result in financial losses for service providers.

2. The new funding policy introduced recently provides a basis for performing VA-ECMO without causing financial losses for service providers.

\section{ACKNOWLEDGEMENTS}

1. Source of funding: none.

2. Conflict of interest: none.

\section{References:}

1. Brown DJA, Brugger $\mathrm{H}$, Boyd J, et al. Accidental hypothermia. N Engl J Med. 2012;367(20): 1930-1938, doi: 10.1056/NEJMra1114208, indexed in Pubmed: 23150960.

2. Central Statistical Office of Poland (2015) Demographic base.

3. Kosiński S, Darocha T, Gałązkowski R, et al. Accidental hypothermia in Poland - estimation of prevalence, diagnostic methods and treatment. Scand J Trauma Resusc Emerg Med. 2015; 23: 13, doi: 10.1186/s13049014-0086-7, indexed in Pubmed: 25655922.

4. Truhlár $A$, Deakin CD, Soar J, et al. Cardiac arrest in special circumstances section Collaborators. European Resuscitation Council Guidelines for Resuscitation 2015: Section 4. Cardiac arrest in special circumstances. Resuscitation. 2015; 95: 148-201, doi: 10.1016/j.resuscitation.2015.07.017, indexed in Pubmed: 26477412.

5. Wróblewska W. Zgony możliwe do uniknięcia - opis koncepcji oraz wyniki analizy dla Polski. Studia Demograficzne. 2012; 161(1).

6. Darocha T, Kosiński S, Jarosz A, et al. Severe Accidental Hypothermia Center. Eur J Emerg Med. 2015; 22(4): 288-291, doi: 10.1097/ MEJ.0000000000000213, indexed in Pubmed: 25304125.
7. Lango R, Szkulmowski Z, Maciejewski D, et al. Protokół zastosowania pozaustrojowej oksygenacji krwi (extracorporeal membrane oxygenation - ECMO) w leczeniu ostrej niewydolności oddechowej Zalecenia i wytyczne Nadzoru Krajowego oraz Konsultanta Krajowego w dziedzinie Anestezjologii I Intensywnej Terapii. Anestezjol Intens Ter. 2009; 41: 253-258.

8. Ładny JR, Kusza K, Knapik P. Zalecenie dla personelu szpitalnych oddziałów ratunkowych/izb przyjęć. http://www.hipotermia.edu.pl/.

9. Dunne B, Christou E, Duff O, et al. Extracorporeal-assisted rewarming in the management of accidental deep hypothermic cardiac arrest: a systematic review of the literature. Heart Lung Circ. 2014; 23(11): 1029-1035, doi: 10.1016/j.hlc.2014.06.011, indexed in Pubmed: 25043580.

10. Ruttmann $\mathrm{E}$, Weissenbacher $\mathrm{A}, \mathrm{U}$ Imer $\mathrm{H}$, et al. Prolonged extracorporeal membrane oxygenation-assisted support provides improved survival in hypothermic patients with cardiocirculatory arrest. JThorac Cardiovasc Surg. 2007; 134(3): 594-600, doi: 10.1016/j.jtcvs.2007.03.049, indexed in Pubmed: 17723804.

11. Debaty G, Moustapha I, Bouzat P, et al. Outcome after severe accidental hypothermia in the French Alps: A 10-year review. Resuscitation. 2015; 93: 118-123, doi: 10.1016/j.resuscitation.2015.06.013, indexed in Pubmed: 26095302.

12. Darocha T, Kosiński S, Jarosz A, et al. The chain of survival in hypothermic circulatory arrest: encouraging preliminary results when using early identification, risk stratification and extracorporeal rewarming. Scand J Trauma Resusc Emerg Med. 2016; 24: 85, doi: 10.1186/s13049-0160281-9, indexed in Pubmed: 27357577.

\section{Corresponding author:}

Tomasz Darocha, MD, PhD

Department of Anaesthesiology

and Intensive Care

with Cardiac Monitoring

Independent Public Central

Clinical Hospital No 7

of the Silesian Medical

University in Katowice,

Leszek Giec Upper-Silesian

Medical Centre

Ziołowa 45/47, 40-635 Katowice

e-mail:tomekdarocha@wp.pl

Received: 5.11.2016

Accepted: 18.03.2017 